УДК 343.98

DOI https://doi.org/10.32837/pyuv.v0i1(30).544

\author{
Л. В. Полуніна \\ orcid.org/0000-0002-8898-2162 \\ старший викладач кафедри фінансових розслідувань \\ факультету підготовки, перепідготовки \\ та підвищення кваліфікації працівників податкової міліції \\ Університету державної фіскальної служби України
}

\title{
ОСОБЛИВОСТІ ТАКТИКИ ПРОВЕДЕННЯ СЛІДЧИХ (РОЗШУКОВИХ) ДІЙ ПІД ЧАС РОЗСЛІДУВАННЯ НЕЗАКОННОГО ЗБИРАННЯ ТА РОЗГОЛОШЕННЯ КОМЕРЦЙНОЇ АБО БАНКІВСЬКОЇ ТАЄМНИЦІ
}

Постановка проблеми. Успіх та ефективність зайняття підприємницькою діяльністю суттєво залежать від ступенів її захищеності від ризиків, пов'язаних із розголошенням інформації, що становить комерційну таємницю. Досвід показує, що промислове шпигунство може завдати підприємству не меншої шкоди, ніж економічна криза, необгрунтовані управлінські рішення та ін. На жаль, цьому питанню приділяється мало уваги, оскільки наслідки промислового шпигунства, як правило, виявляються не відразу, відсутній досвід розкриття (виявлення) та розслідування вказаних злочинів, проведення слідчих (розшукових) дій під час розслідування.

Відповідальність за незаконне збирання з метою використання або використання відомостей, що становлять комерційну або банківську таємницю, передбачена ст. 231 Кримінального кодексу України (далі - КК України), відповідальність за розголошення комерційної або банківської таємниці передбачена ст. 232 КК України.

Аналіз останніх досліджень. Окремі питання розслідування розголошення комерційної або банківської таємниці вже були предметом розгляду науковців, зокрема А.А. Івахова [1], Р.Н. Белінського [2], В.М. Іващенка [3], I.С. Сербіна [4], I.Б. Ткачука [5], А.А. Топоркова [6], О.В. Курмана [7]. Однак проблеми проведення слідчих (розшукових) дій у процесі розслідування вказаного злочину в публікаціях розглядалися поверхнево, інколи з використанням кримінального процесуального законодавства, яке втратило чинність.

Метою статті є аналіз тактики проведення основних слідчих (розшукових) дій під час розслідування незаконного збирання та розголошення комерційної або банківської таємниці.

Виклад основного матеріалу. Кримінальні провадження за фактами незаконного збирання з метою використання або використання відомостей, що становлять комерційну таємницю або банківську таємницю, а також розголошення комерційної або банківської таємниці, здебільшого розпочинаються за заявами або повідомленнями представників суб'єктів господарювання - керівників підприємств, установ, організацій, представ- ників служб або підрозділів безпеки юридичних осіб, фізичних осіб-підприємців, членів експертних комісій із захисту комерційної таємниці суб'єктів господарювання, зокрема, керівників і спеціалістів структурних підрозділів юридичної особи та інших осіб. Рідше підставами для початку кримінального провадження можуть слугувати повідомлення, опубліковані в пресі [8, с. 145-151].

Початок кримінального провадження є правовою підставою для проведення слідчих (розшукових) дій і застосування передбачених законом заходів забезпечення кримінального провадження. Ці дії та заходи закон пов'язуе з конкретним кримінальним провадженням. На стадії початку кримінального провадження не тільки вживають заходів щодо встановлення підозрюваної у вчиненні злочину особи, а й запобігають через застосування заходів процесуального примусу можливості продовження нею злочинної діяльності [9, с. 199-205].

Кримінальний процесуальний кодекс України (Глава 20. Слідчі(розшукові)діï)[10]визначає види і зміст різноманітних процесуальних дій, що здійснює уповноважена особа на досудовому слідстві, i тому називає їх слідчими (розшуковими) діями.

Черговість слідчих (розшукових) дій у кримінальних провадженнях, розпочатих за фактами незаконного збирання з метою використання або використання відомостей, що становлять комерційну таємницю або банківську таємницю, а також розголошення комерційної або банківської таємниці, їх послідовність залежать від конкретної слідчої ситуації, що склалася на початковому етапі розслідування.

До типових слідчих ситуацій, характерних для початкового етапу розслідування незаконного збирання та розголошення комерційної або банківської таємниці, пропонуємо зарахувати такі:

1) факт незаконного збирання та розголошення комерційноїабобанківськоїтаємницівстановлено, наявна інформація про спосіб вчинення злочину, шкідливі наслідки, щонастали, але немає інформації про особу правопорушника чи групу таких осіб;

2) факт настання шкідливих наслідків встановлено, але причини таких наслідків відсутні (наприклад, пожежа в суб'єкта господарювання, 
який володіє комерційною або банківською таємницею, що може замаскувати вчинення незаконного збирання комерційної або банківської таємниці і т. ін.);

3) є відомості про подію правопорушення і запідозрену особу, але немає твердої впевненості, що ця подія мала місце (наприклад, заява потерпілої сторони про збирання та розголошення комерційної або банківської таємниці конкретною запідозреною особою і т. ін.);

4) відома інформація про незаконне збирання та розголошення комерційної або банківської таємниці, спосіб вчинення правопорушення, його шкідливі наслідки, є інформація про запідозрену особу, але більшість цих відомостей мають непроцесуальний характер [11, с. 250-256].

На нашу думку, найчастіше зустрічаються наступніслідчі(розшукові)дії:допитзаявника(потерпілого), допит свідків (ст. 225 КПК України), огляд (ст. 237 КПК України), обшук (ст. 234 КПК України), слідчий експеримент (ст. 240 КПК України).

Огляд місця (приміщення) зберігання документа проводиться з метою виявити і зафіксувати такі обставини: 1) сутність (характерні риси, особливості) порушень правил конфіденційного діловодства: а) відсутність передбачених правилами засобів технічного захисту приміщення, території (огорож, охоронної сигналізації тощо); б) неналежний технічний стан захисних засобів внаслідок їх несправності або інших причин; в) порушення правил зберігання основного і запасного ключів від сховища (сейфу); г) порушення правил здачі приміщення для охорони (у тому числі включення охоронної сигналізації); г) наявність доказів (фактів) використання службового приміщення не за призначенням (для зустрічей зі сторонніми особами, вживання алкогольних напоїв, наркотичних засобів тощо), фактів неналежного зберігання документів (поза сейфом, сховищем); 2) перебування у службовому приміщенні сторонніх осіб: а) сліди ніг, рук, пальців, крові, слини, одягу; б) сліди вживання їжі, спиртних напоїв, куріння; в) сліди відправлення природних потреб; г) зникнення окремих предметів, зміна положення і місцезнаходження предметів, меблів, технічних засобів, засобів зв'язку; г) сліди використання предметів, приладів, обладнання; 3) сліди проникнення правопорушника на територію (у приміщення): а) сліди рук, ніг (взуття) на огорожі, зовнішніх стінах будівлі, підвіконні; б) сліди застосування знарядь злому та інших засобів (мається на увазі також їх виявлення, фіксація і вилучення); в) сліди пошкодження огорожі, вікон, дверей, підлоги, стелі; г) сліди пошкодження цілісності печатки; І) сліди відключення, пошкодження охоронної сигналізації, приладів освітлення.

Огляд сховища (сейфу) здійснюється з метоювиявити і зафіксувати такі обставини: 1) сліди порушення правил користування сховищем (сейфом): а) несправність замка, корпусу, що надає доступ у сховище без ключа; б) відмикання замка сейфу дублікатом ключа; порушення правил опечатування сейфу; в) наявність у сейфрі сторонніх предметів, цінностей, документів, літератури; 2) сліди правопорушника: а) сліди рук, ніг, взуття, одягу на корпусі сейфу; б) сліди пошкодження корпусу або замка (злом, розпил, свердління, віджимання); в) сліди вилучення документів через ушкоджену частину корпусу (волокна паперу, наявність сторонніх нашарувань на закраїнах щілини, отвори); г) порушення цілісності печатки (у тому числі повне знищення без відновлення); г) сліди тимчасового (з подальшим відновленням) видалення печатки шляхом зрізання, заморожування тощо; д) опечатування сейфу іншою печаткою; е) сліди викрадача усередині сейфу (відбитки пальців на внутрішній поверхні сейфу); є) сліди біологічного походження (частинки шкірних покривів від саден, кров; мікросліди - відшарування від одягу тощо); ж) сліди відмикання замка нештатним ключем або відмичкою (наявність мастила, пасти, мастики, металічних ошурків у коробці замка, траси на кришці коробки замка).

Огляду також підлягають: 1) засоби обчислювальної техніки; 2) засоби зв' язку і передачі даних обчислювальної техніки; 3) засоби телефонного зв'язку, звукозапису, звукопідсилення, переговорніітелевізійніприлади; 4)засобивиготовлення, тиражування документів та інші технічні засоби обробки інформації; 5) засоби охоронної і пожежної сигналізації; 6) засоби оповіщення і сигналізації; 7) контрольно-вимірювальна апаратура; 8) засоби і системи кондиціювання; 9) засоби провідної радіотрансляційної мережі; 10) засоби електронної оргтехніки; 11) електронні годинники тощо.

3 метою встановлення обставин втрати документа доцільно проводити: 1) допит особи, відповідальної за документ, під час якого ставляться запитання, коли і у зв'язку з чим був нею отриманий документ; чи було дотримано встановлений порядку його отримання; коли і у зв'язку з чим була виявлена нестача документа; чи відомі обставини і причини виходу документа з володіння; чи допускалися порушення правил поводження з отриманим документом; 2) допит осіб, які виявили нестачу документа, з метою встановити, коли i за яких обставин була виявлена нестача; чи проявляв хто-небудь ознаки усвідомлення про неї до їі виявлення; чи відомо свідку про обставини виходу документа з володіння відповідальної особи; які зміни вносилися в обстановку місця зберігання документа до початку досудового розслідування.

Необхідно зауважити, що особливої уваги потребує проведення допиту осіб, які виявили факт перехоплення інформації, що становить комерційну таємницю підприємства і циркулює в технічних засобах і приміщеннях. 
Допитуючи підозрюваного, необхідно пам'ятати, що несанкціонований доступ до закритих комп'ютерних систем чи мереж із метою незаконного збирання інформації, що циркулюе в них і становить комерційну таємницю, може бути вчинений лише фахівцем. У підозрюваних, за достатніх підстав, проводиться обшук за місцем роботи і проживання. Під час обшуку звертають увагу на комп'ютери різних конфігурацій, принтери, засоби телекомунікації з комп'ютерними системами, записні книжки, у тому числі електронні, дискети, компакт-диски, флеш карти, магнітні стрічки, що містять відомості про коди, паролі, ідентифікаційні номери користувачів конкретною комп'ютерною системою, а так само дані про іï користувачів.

Наявністю окремих тактичних особливостей характеризується і проведення слідчого експерименту, оскільки метою проведення цієї слідчої дії наступного етапу розслідування незаконного збирання з метою використання відомостей, що становлять комерційну таємницю, є: а) перевірка висунутої версії про можливість (або неможливість) перехоплення відомостей, які циркулюють у конкретних технічних засобах і приміщенні, шляхом використання відомих спеціалістам способів і пристроїв; б) перевірка показань підозрюваного, свідка про таке, що мало місце, перехоплення відомостей у конкретних умовах із використанням конкретного способу і пристрою; в) перевірка параметрів і можливостей технічного пристрою, програми EOM, запроваджених підозрюваним, iз метою незаконного перехоплення конфіденційної інформації і виявлених у результаті проведення слідчих дій тощо [5, с. 137].

Під час проведення обшуку необхідно вилучати: 1 ) журнали обліку робочого часу і доступу до обчислювальної техніки, збоїв і ремонту, реєстрації користувачів комп'ютерною системою чи мережею; проведення регламентованих робіт; 2) книги паролів; 3) накази та інші документи, що регламентують роботу установи. Багато документів зберігаються в електронній формі, і з метою їх вилучення необхідно запрошувати фахівців.

Крім цього, варто зазначити, що проведення всіх перерахованих слідчих (розшукових) дій необхідно здійснювати відповідно до процесуального порядку, який передбачений чинним КПК України (ст. 223 КПК України).

Проведення слідчих (розшукових) дій у кримінальних провадженнях, розпочатих за фактами про незаконне збирання з метою використання або використання відомостей, що становлять комер- ційну таємницю суб'єкта господарської діяльності, а також розголошення комерційної таємниці 3 дотриманням наукових рекомендацій, а також 3 урахуванням зазначених тактичних особливостей сприятиме систематизованому та всебічному пошуку слідів злочинної діяльності, їх вилученню, успішному попередньому дослідженню та отриманню важливої криміналістично значимої інформації ще на початковому етапі розслідування.

\section{Jimepamypa}

1. Івахов А.А. Проблемні питання у розслідуванні кримінальних справ про розголошення державної таємниці та шляхи їх вирішення в умовах реформування кримінальної юстиції України. Питання удосконалення діяльності органів дізнання та досудового слідства в уловах реформування кримінальної юстииї України : матеріали наук.-практ. конф., Харків, 30 трав. 2008 р. / Ін-т підготовки юрид. кадрів для Служби безпеки України. Харків, 2008. С. 113-117.

2. Белинский Р.Н. Использование непроцессуальной информации по уголовным делам о незаконном получении и разглашении сведений, составляющих коммерческую тайну (досудебное производство) : автореф. дис. ... канд. юрид. наук. Москва, 2008. 25 с.

3. Іващенко В.М. Окремі положення методики розслідування незаконного збирання та розголошення комерційної таємниці. Право і суспільство. 2006. № 2. С. 50-58.

4. Сербин И.С. Незаконное собирание сведений, составляющих коммерческую тайну: характеристика личности преступника. Крилиналистика. Экспертиза. Розыск : сборник научных статей. Саратов : СЮИ МВД России, 2007. Вып. 1. С. 344-351.

5. Ткачук И.Б. Коммерческая тайна: организация защиты, расследование посягательств. Москва : изд-во «Щит-М», 2000. 168 c.

6. Топорков А.А. Криминалистика : учебник. Москва : Юстиция, 2016. $544 \mathrm{c.}$

7. Курман О.В. Відомості, що становлять комерційну таємницю, як предмет злочинного посягання. Право і суспільство. 2015. № 5.2 (2). С. 177-181.

8. Полуніна Л.В. Висунення версій та планування на початковому етапі розслідування незаконного збирання з метою використання або використання відомостей, що становлять комерційну або банківську таємницю. Актуальні проблеми правознавства. 2019. Випуск 1 (17). С. 145-151.

9. Назаров В.В., Омельяненко Г.М. Кримінальний процес України : підручник. Київ : Юридична думка, 2005.548 c.

10. Кримінальний процесуальний кодекс України : Закон України від 13.04.2012 р. № 4652-VI. Верховна Рада України. URL: https://zakon.rada.gov.ua/laws/ show/4651-17.

11. Полуніна Л.В. Типові слідчі ситуації та процесуальні дії щодо їх вирішення під час розслідування незаконного збирання та розголошення комерційної та банківської таємниці. Міжнародний юридичний вісник: актуальні проблеми сучасності (теорія та практика). 2018. Випуск 3-4 (12-13). С. 250-256. 


\section{Анотація}

Полуніна Л. В. Особливості тактики проведення слідчих (розшукових) дій під час розслідування незаконного збирання та розголошення комерційної або банківської таємниці. - Стаття.

Проблема розкриття та здійснення досудового розслідування, зокрема, і проведення слідчих (розшукових) дій у кримінальних провадженнях, розпочатих за фактами незаконного збирання з метою використання або використання відомостей, що становлять комерційну таємницю суб'єкта господарської діяльності, а також розголошення комерційної таємниці, безперечно є. Вона зумовлена відсутністю достатніх правових знань з організації та методики розслідування, тактики проведення слідчих (розшукових) дій слідчими органами, а також відсутністю юридичної літератури та наукових розробок із цієї тематики.

У статті частково розкрито та проаналізовано першочергові слідчі (розшукові) дії, які необхідно проводити при отриманні інформаціїпрофакти незаконногозбирання з метою використання або використання відомостей, що становлять комерційну або банківську таємницю.

Водночас у статті виокремлені типові слідчі ситуації, характерні для початкового етапу розслідування незаконного збирання та розголошення комерційної або банківської таємниці, та встановлено, що черговість слідчих (розшукових) дій у кримінальних провадженнях, розпочатих за фактами незаконного збирання 3 метою використання або використання відомостей, що становлять комерційну таємницю або банківську таємницю, а також розголошення комерційної або банківської таємниці, їх послідовність залежить від конкретної слідчої ситуації, що склалася на початковому етапі розслідування.

Вперше визначено, які саме слідчі (розшукові) дії необхідно проводити в першу чергу в процесі розслідування незаконного збирання з метою використання або використання відомостей, що становлять комерційну таємницю або банківську таємницю. Розглянуто процесуальний порядок та тактику їх проведення.

Проведення вказаних слідчих (розшукових) дій із дотриманням наукових рекомендацій та врахуванням певних тактичних особливостей сприятиме отриманню криміналістично значимої доказової інформації вже на початковому етапі розслідування незаконного збирання та розголошення комерційної таємниці.

Ключові слова: комерційна таємниця, банківська таємниця, слідчі (розшукові) дії, допит, огляд, обшук, слідчий експеримент.

\section{Summary}

Polunina L. V. Features of the tactics of investigative (search) actions in the investigation of the illegal collection and disclosure of commercial or bank secrets. Article.

The problem of disclosing and conducting pre-trial investigation, in particular, and conducting investigative (search) actions in criminal proceedings, initiated on the facts of illegal collection for the purpose of using or using information constituting the commercial secret of a business entity, as well as the disclosure of commercial secret, undoubtedly exists. It is due to the lack of sufficient legal knowledge on the organization and methods of investigation, the tactics of investigative (search) actions by the investigating authorities, as well as the lack of legal literature and scientific developments on this topic.

The article has partially disclosed and analyzed the primary investigative (search) actions that must be carried out when obtaining information about the facts of illegal collection in order to use or use information constituting a commercial or banking secret.

At the same time, the article identifies typical investigative situations typical of the initial stage of the investigation of the illegal collection and disclosure of commercial or banking secrets and establishes that the sequence of investigative (search) actions in criminal proceedings initiated on the facts of illegal collection for the purpose of using or using information constituting trade secret or bank secret, as well as the disclosure of commercial or bank secret, their sequence depends on the specific investigative situation, which The first one was formed at the initial stage of the investigation.

For the first time, it was determined what kind of investigative (search) actions should be carried out first of all when investigating an illegal collection with the aim of using or using information constituting a commercial secret or a bank secret. The procedural order and tactics of their implementation are considered.

Carrying out the indicated investigative (search) actions in compliance with scientific recommendations and taking into account certain tactical features helps to obtain forensic evidence at the initial stage of the investigation of the illegal collection and disclosure of trade secrets.

Key words: commercial secret, bank secret, investigative (search) actions, interrogation, inspection, search, investigative experiment. 